\title{
INNOVATION AND PUBLIC SECTOR PERFORMANCE: EVIDENCE FROM LAGOS INTERNAL
} REVENUE SERVICES

\author{
EZE, Benneth Uchenna ${ }^{1}$, ADELEKAN,Saidi Adedeji $\mathrm{PhD}^{2}$, MAJEKODUNMI, Samuel Ayodele ${ }^{3} \& N W A B A$, \\ Kanayo Emmanuel ${ }^{4}$ \\ Department of Business Administration, Faculty of Management and Social Sciences, Hallmark University, Ijebu \\ Itele, Ogun State, Nigeria ${ }^{1}$. \\ Department of Business Administration, College of Humanities, Management Sciences and Social Sciences, \\ Mountain Top University, Km 12, Lagos-Ibadan Express Way, Prayer City, Nigeria ${ }^{2,3}$. \\ Department of Business Administration, Olabisi Onabanjo University, Ago-Iwoye, Ogun State, Nigeria ${ }^{4}$ \\ Corresponding Author: Adelekan, Saidi Adedeji, (PhD) \\ Email:saadelekan@mtu.edu.ng \\ DOI: $10.36108 /$ ljerhrm/8102.01.0161
}

\begin{abstract}
The study examines the effect of innovation (measured by e-assessment and e-payment) on public sector performance (measured by the revenue generation of Lagos Internal Revenue Service 'LIRS').The study employs survey research design, through the administration of structured questionnaire to staff of Lagos Internal Revenue Service (LIRS). The population of the study is the 2630 staff of LIRS, and using Yamane sample size determination formula at 95\% confidence level and 5 margin of error, a sample size of 347 was obtained. 347 copies of questionnaire were administered to the targeted respondents. However, 241 copies of the questionnaire were returned and found useable, which represent 69.45\% return rate. Content validity index and Cronbach Alpha was employed in testing the validity and reliability of the instrument (questionnaire). The findings reveal that eassessment $\left(\beta_{1=} 0.477, \mathrm{p}\right.$-value $\left.<0.05\right)$ and e-payment $\left(\beta_{2=} 0.840, \mathrm{p}\right.$-value $\left.<0.05\right)$ have positive and significant individual and combined effect on public sector performance, particularly the revenue generation of LIRS ( $F$ stat $=122.744 * 0.000$ ). The adjusted coefficient of determination (adjusted $R^{2}$ ) suggested that $81.3 \%$ variation in the revenue generation of LIRS is accounted for by e-assessment and e-payment. It can therefore be concluded that the process innovativeness of LIRS, particularly the introduction of e-assessment and e-payment have enhanced the revenue generation of LIRS. It is recommended that public enterprises should enhance their innovativeness, through the introduction of innovative process, which will ease the transactional activities, especially the introduction of internet enabled processes and services, where customers or clients can transact with public enterprises online without visiting the offices of such enterprises.
\end{abstract}

Keywords: Innovation, Public Enterprises, Revenue, E-Assessment, E-Payment, LIRS

\section{Introduction}

The Nigerian economy is facing significant challenges, as the economy adjusts to shortages in foreign currency, which was occasioned by low power generation, lower oil revenue and weak investors' confidence. This has substantially affected the nation's fiscal and external accounts just as it negatively affects monthly allocations to the federating units (Federal, State and Local Governments) from the federation account (International Monetary Fund (IMF,9i9i 2016). Considering the present uncertain global outlook and the likelihood of crude oil prices remaining low, it therefore becomes necessary for government at various levels to generate more funds internally, by enhancing the financial performance of public enterprises, in order to augment the public finance gap.

Studies (Rababah, 2017; Frank, Muturi \& Gerrad, 2017;Gunday, Ulusoy, Kilic \& Alpkan, 2011; Nwankwo \& Ajemunigbohun, 2016; Adelekan, 2017) have shown that innovativeness impacts firms' performance. Innovation echoes an enterprise proclivity to get involved in, and sustain, distinctiveness, experimentation, novel ideas, and inventive processes that might lead to the creation of new product,technique and market (Lumpkin \& Dess, 1996; Adelekan, 2016; Eze, 2017).

Literature on the relationship between innovation and firms' performance abounds as numerous studies have been conducted in developing, emerging and developed economies, including Nigeria. However, most of the studies (Rababah, 2017; Frank et al., 2017; Gunday et al., 2011; Nwankwo \& Ajumogbohun, 2016) focused on how innovation has impacted private enterprises' performance. While the few studies (Onu, Obiyo, Igbo \& Ezeanwu, 2012; Romero-Martinez, Fernandez-rodngue \& Vazguez-inchausti, 2010) that examined the relationship between innovation and public enterprises' performance focused on public educational institutions and public private partnership. 
The relationship between innovation and public enterprises performance appear not to have been fully examined. In addressing this research gap, this study examines the relationship between innovation and the performance of public enterprise, with focus on the Lagos Internal Revenue Service (LIRS).

\section{Literature Review}

The need for enterprises to be innovative to be able to deal with competitive pressure cannot be overemphasized. Innovation is usually the outcome of business challenges that an enterprise has to deal with and the solution to overcome these challenges depends on the development of new product, market as well as the technique, that is, the process (Oladimeji, Abosede \& Eze, 2017).

Innovation reverberate an enterprise proclivity to get involved in, and sustain, distinctiveness, experimentation, novel ideas, and inventive processes that might lead to the creation of new product, technique and market (Lumpkin \& Dess, 1996). Innovative enterprises have the capability to examine the changes in the market and act swiftly, in order to take advantage of promising opportunities (Wiklund \&Shepherd, 2003; Awosika, 2015).

Innovation is the development of new wealth or the modification and enhancement of existing resources to create new wealth. Innovation is also seen as a process of a novel idea generation, a progression of an invention, which can lead to the introduction of new product, process or market. Innovation is not just aimed at solving problem, but providing solution.

Scholars (Oke, Munshi\& Walumbwa, 2009; Durst, Mention \& Poutanen, 2014; Maduenyi, Oke, Fadeyi \&Ajagbe, 2015) identify various kinds of innovation, which include: process innovation, product innovation, market innovation, organizational innovation, service innovation. This study focuses on the process (techniques) innovativeness of Lagos Internal Revenue Service (LIRS). According to Okeet al. (2009) process innovation is the creation of, or enhancement in techniques and production system or process development. It involves reengineering as well as improving the internal operation of business process. For instance, innovation in techniques, skill, system and procedure, which is employed in the transformation of input into output that leads to efficiency in organizations. LIRS introduced electronics payment (e-payment) and electronics assessment (eassessment). These innovative processes allow payment into government coffers through electronic channels.

Payments into the government coffers were electronically linked to data bases that issued electronic receipt to taxpayers and closely monitored by an independent consultant to the State. Personal electronic tax clearance cards (e-TCC) were introduced, this made tax collection more transparent to the taxpayers as they could access their records via the internet, and this made tax payments, more convenient to the taxpaying public. Taxpayers could also obtain electronics tax assessment from the LIRS website without visiting any of the LIRS offices across the state; this has equally enhanced the ease of payment (www.lirs.gov.ng)

\section{Public Enterprises}

Public enterprises have long been a very important part of the public sector of most developed, emerging and developing economies of the world. Apart from the civil service, there is the creation and development of public enterprises that combine the attributes of public administration with some features of private enterprises. These enterprises are usually created to stimulate and enhance national development under conditions of private capital shortage (Anyebe, 2015).

According to Laleye (2002)“a public enterprise is an organization set-up as a corporate body and as part of government apparatus for entrepreneurial or entrepreneurial-like objective. The enterprise is essentially commercial, requires greater latitude than would be typical, and would acquire at least a portion of its funding in the market place" (p. 28).

It is an entity created by law or act of the parliament or a decree. The law defines its organization structure, functions and powers. It is a state-owned entity created by law and strives towards the attainment of national objectives.The Nigerian government at federal, state and local government levels have been actively involved in economic activities since the indigenization policy of 1972, the policy was designed to give Nigerians the opportunity to control the nation's economy, unlike what was obtainable before the implementation of the policy, when foreigners controlled the nation's economic activities (Okeke, Onuorah \& Okonkwo, 2016). The nonperformance of most public enterprises has propelled the government to privatize a good percentage of such entities. Nevertheless, some public enterprises and agencies have been recording appreciable performance over the last two decades; one of such public sector entities is the Lagos Internal Revenue Service. 
The Lagos Internal Revenue Service (LIRS),is the major revenue generating agency of the Lagos State Government saddled with the responsibility of collecting taxes. The Agency has consistently increased the state internally generated revenue (IGR). The IGR increased from a quarterly average of about NGN 1.8 Billion in 1999 to NGN 84.19 Billion as at the first quarter of 2018, which has made Lagos State to depend less on proceeds from the federation account (www.lirs.gov.ng).

Lagos Internal Revenue Service put in place creative and innovative measures that could enhance revenue generation such as simplifying the procedures of internal revenue generation, transparent as well as improving taxpayers' education; effective use of automated systems especially in the clearing system and monitoring refund claims; and strengthening electronic assessment of taxpayers, administration including staff investigative machinery and human capacity building in the state(Asaolu, Dopemu \& Monday, 2015).

\subsection{Theoretical Framework}

\subsubsection{Ambidexterity Theory}

Bledow, Frese, Anderson, Erez, and Farr (2009) put forward ambidexterity theory to explain the process of managing conflicting demands at multiple organizational levels to successfully innovate. Ambidexterity refers to "the ability of a complex and flexible system to manage and meet conflicting demands by engaging in fundamentally different activities" (Bledow et al., 2009). Generally ambidexterity implies successful management of both, exploration and exploitation in term of products, that is, the creation of a new process, product and the convertion of idea from the conceptual stage to reality. In terms of integration of activities, Bledow et al.,(2009) suggest differences between active management and self-regulatory processes. They posit that both are required for the combination of similar activities performed by levels, components or at different points in time (Bledow et al., 2009).

\section{Methodology}

The study employs survey research design, through the administration of structured questionnaire to staff of LIRS. The questions capturing innovation was adapted from Linyiru (2014) while the questions for e-assessment and epayment was developed by the researchers. The population of the study is the 2630 staff of LIRS and using Yamane (1967) sample size determination formula at 95\% confidence level and 5 margin of error, a sample size of 347 was obtained.347 copies of questionnaire were administered to the targeted respondents. However, 241 copies of the questionnaire were returned and found useable, which represent $69.45 \%$ return rate.A seven-point Likert Scale questionnaire ranging from 1 (Minimum) to 7 (Maximum) was employed.

The instrument was validated using content validity index(CVI) through the evaluation of two academics and two top staff of Lagos internal revenue service, theyassessed the instrument on two-point scale(relevant and nonrelevant).

Using the CVI formula:

$\mathrm{CVI}=\mathrm{n} / \mathrm{N}$

Where;

$\mathrm{n}=$ Number of questions ticked as relevant

$\mathrm{N}=$ Total number of question

A CVI of 0.88 was obtained, which indicated that the instrument is valid.

A pilot study was conducted to test the reliability of the instrument (questionnaire). The instrument was administered to ten staff of LIRS at Idimu, Lagos tax station twice within an interval of two weeks. The result of first pilot study was correlated with the second to obtain a Cronbach alpha of $0.83,0.90$ and 0.81 for eassessment, e-payment and revenue respectively.

\section{Statement of Hypotheses}

Ho1: e-assessment does not significantly affect LIRS performance

Ho2: e-payment does not significantly affect LIRS performance

Ho3: e-payment and e-assessment do not significantly affect LIRS performance 


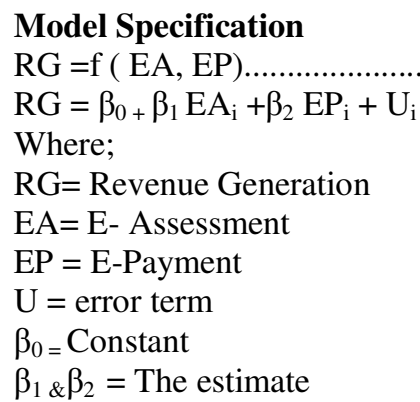

Apriori expectation: It is expected that e- assessment and e-payment will positively affect LIRS revenue generation. Hence, the parameters of e-assessment and e-payment should take a positive sign.

For analyzing the primary data, categorical regression was employed to examine the effect of the independent variable (innovation) on the dependent variable (Revenue Generation). This was achieved with the aid of SPSS version 24.

\section{Results and Discussions}

Table 4.1: Summary of Categorical Regression Result (Dependent Variable - Public Enterprise Performance 'Revenue Generation')

\begin{tabular}{|c|c|c|c|}
\hline Variable(s) & Coefficient & $\mathrm{F}$ & P-Value \\
\hline E- Payment & $.840^{*}$ & 24.789 & 0.000 \\
\hline E- Assessment & $.477^{*}$ & 11.243 & 0.000 \\
\hline N.B:*:Signific & evel & \multicolumn{2}{|c|}{$\begin{array}{l}\text { R-Square }=0.820 \text { Adj R-Square }=0.813 \\
\text { F-statistics }=122.744(* 0.000)\end{array}$} \\
\hline
\end{tabular}

\section{Author's computation from SPSS 24 Source: Field survey (2018)}

The result summary on Table 4.1 above revealed that e-assessment and e-payment have positive and significant combined effect on public sector performance, particularly the revenue generation of LIRS $(\mathrm{F}$-stat $=122.744$ $* 0.000$ ). The adjusted coefficient of determination (adjusted $\mathrm{R}^{2}$ ) suggested that $81.3 \%$ variation in the revenue generation of LIRS is accounted for by e-assessment and e-payment, while the F-value (122.744*0.000) suggested that all the parameter estimates are significant. However, the individual significant level revealed that, e-payment has the most effect on the revenue generation of LIRS.

This is consistent with the study by Onu, Obiyo, Igbo \& Ezeanwu (2012) that found that innovation is positively related to public educational institutions performance. It also agrees with Romero-Martinez, Fernandez-rodngue \& Vazguez-inchausti (2010) that innovation is positively related to the performance of public-private partnership entities.

\section{Conclusion and Recommendation}

The study examines the effect of innovation (measured by e-assessment and e-payment) on public sector performance (measured by the revenue generation of Lagos Internal Revenue Services 'LIRS'), using survey research design. The findings reveal that e-assessment and e-payment have positive and significant combined effect on public sector performance, particularly the revenue generation of LIRS (F-stat= 122.744 *0.000). The adjusted coefficient of determination (adjusted $\mathrm{R}^{2}$ ) suggested that $81.3 \%$ variation in the revenue generation of LIRS is accounted for by e-assessment and e-payment.

It can therefore be concluded that the process innovativeness of LIRS, particularly the introduction of eassessment and e-payment have enhanced the revenue generation of LIRS. It is recommended that public enterprises should enhance their innovativeness through the introduction of innovative process, which will ease the transactional activities, especially the introduction of internet enabled services and processes, where customers or clients can transact with public enterprises online without visiting the offices of such enterprises. The relative higher internet penetration rate in Nigeria has also provided ample opportunities for public enterprises to deploy internet enabled innovative process and service as well as innovatively expanding their market, through the enormous opportunities provided by the internet. 


\section{References}

Adelekan, S.A. (2016). The impact of organisational culture on innovation capability of SMES case study of SMES in Alimosho and Ojo Local Government Area of Lagos State, Nigeria. International Journal of Economics, Commerce \& Management, 6(9), 158-181.

Adelekan, S.A. (2017). Entrepreneurship. First edition. Wallex Pub. Lagos, Nigeria.

Anyebe, A.A. (2015). A reflection on public enterprise sector in Nigeria. International Journal of Development and Sustainability, 4(4), 348-358.

Asaolu, T. O.,Dopemu, S. O. \& Monday, J. U. (2015).Impact of tax reforms on revenue generation in Lagos State: A time series approach. Research Journal of Finance and Accounting 6(8).

Awosika, F.O. (2015). Transforming public service performance in West Africa through innovations: Experiences from Ghana and Nigeria. Africa's Public Service Delivery \&

Bledow, R., Frese, M., Anderson, N., Erez, M., \& Farr, J. (2009). A dialectic perspective on innovation: Conflicting demands, multiple pathways, and ambidexterity. Industrial and Organizational Psychology, 2(3), 305-337.

Durst, S., Mention, A. \& Poutanen, P.(2014). Service innovation and its impact: What do we know about? Investigaciones Europeas de Dirección y Economía de la Empresa, 21 (1), 65-72

Eze, B.U. (2017, November). Corporate entrepreneurship and manufacturing firms' performance. Paper presented at the Lagos State University International Conference of Business Administration, Lagos, Nigeria.

Frank, I., Muturi, P. \& Gerad, R. (2017). Effect of Innovation strategies on organizationalperformance; A case study of Kigali. European Journals of Business and social Science, 6(6), 29 - 37.

Gunday, G., Ulusoy, G., Kilic, K., \& Alpkan, L. (2016). Effects of innovation types on firm performance. International Journal of Production Economics, 133(2), 662-676.

Laleye, M. (2002). "Public Enterprises" in L. Adamolekun (ed) Public Administration in Africa, Main issues and Selected Country Studies. Ibadan: Spectrum books Limited.

Linyiru, B.M. (2015). Influence of corporate entrepreneurship on the performance of state corporations in Kenya. Unpublished doctoral thesis, Jomo Kenyatta University of agriculture and technology.

Lumpkin, G.T., \& Dess, G.G. (1996). Clarifying the entrepreneurial orientation construct and linking it to performance. Academy of Management Review, 21(1), 135-172.

Maduenyi, S., Oke, A. O., Fadeyi, O., \& Ajagbe, A. M. (2015). Impact of Organisational Structure on Organisational Performance.

Nwankwo, S.I. \& Ajemunigbohun, S.S. (2016). Empirical examination of the Implementation of electronic system in Service delivery. Journal of Economic and Management. 24(2), 113.

OECD (2015). Innovation in science technology and industry. International Conference on Innovation for Inclusive Growth 2,

Oke, A.; Munshi, N. \& Walumbwa, F. (2009). "The Influence of Leadership on Innovation Processes and Activities". Organizational Dynamics, 38(1), 64-72.

Okeke, M.N., Onuorah, A.N., \& Okonkwo, G.I. (2016). Managing the challenges of public enterprises in Nigeria and the privatization option. Arabian Journal of Business and Management Review, 5(11), 45-54.

Oladimeji, M.S., Abosede, A.J., \& Eze, B.U. (2017, November). Corporate entrepreneurship and service firms' performance in Nigeria. Paper presented at the Lagos State University International Conference of Business Administration, Lagos, Nigeria.

Performance Review. 2(3):23-34

Rababah, N.M. (2017). The Psychological empowerment and innovation on firm performance: An empirical study of SMEs in Saudi Arabia. International Journals of Economics, Commerce and management, 5(6), $298-318$.

Romero-Martínez, A.M, Fernández-Rodríguez, Z., \& Vázquez-Inchausti, E. (2010). Exploring corporate entrepreneurship in privatized firms. Journal ofWorld Business, 45(1), 2-8.

Wiklund J., \& Shepherd, D. (2003). Knowledge-based resources, entrepreneurial orientation, and the performance of small and medium-sized businesses. Strategic management journal, 24(2), 13071314.www.lirs.gov.ng

Yamane, T. (1967). Statistics: An introductory analysis, $2^{\text {nd }}$ edition, New York: Harper and Row. 